\title{
An Innovative Approach to Sex Trafficking Research: The Methodological Advancement of Attride-Stirling's Thematic Network Analysis
}

\author{
Avekadavie Parasramsingh Mano* \\ The University of the West Indies \\ ${ }^{*}$ Corresponding Author: Avekadavie Parasramsingh Mano, The University of the West Indies, \\ St Augustine, Trinidad \& Tobago. E-mail: aveka85@yahoo.com
}

(Submitted 11 May 2017; revised 10 October 2017; accepted 21 October 2017)

\begin{abstract}
Research into sex trafficking is considerably lacking despite its increasing global relevance. The trafficking in human beings has been documented within the literature as a form of modern-day slavery. It is commonly described as a form of organized crime that is highly profitable, involving the active participation of corrupt officials, politicians, financial institutions and criminal networks that facilitate document forgery, illegal border crossings, money laundering and the return of escaped victims. This paper discusses the thematic network analysis of recently collected qualitative data on sex trafficking in Belize. Jennifer Attride-Stirling's (2001) thematic network analysis was applied to data gathered from face-to-face, semi-structured interviews with four distinct groups within the sex industry: sex traffickers, sex workers, clients and knowledgeable locally based officials Given the expansive nature of this research, thematic network analysis has been advanced to accommodate the specificities of each group, creating what has been termed here as a supra-global theme. This innovative approach facilitates the emergence of a deeper, more pertinent understanding of the intrinsic realities characteristic of Belize's sex industry and may be applied to similar multi-group research.
\end{abstract}

Keywords Belize; human trafficking; sex trafficking; supra-global theme; thematic network analysis

Sex trafficking is often perceived as a complex and organized, business-oriented activity (United Nations Global Initiative to Fight Human Trafficking 2008; Jayson 2013). Its intention is to secure maximum monetary rewards through the sexual exploitation of vulnerable people, vulnerability being understood here as "a condition resulting from how individuals negatively experience the complex interaction of social, cultural, economic, political and environmental factors that create the context for their communities" (United Nations Global Initiative to Fight Human Trafficking 2008, p. 69).

Traffickers appear to operate with impunity, having the cooperation of corrupt authorities who help in facilitating the trade. Sex trafficking is a major facet of human 
trafficking, and has been recognized within the literature as a modern-day version of the trans-Atlantic slave trade, the difference being that it has grown in sophistication (see Raymond et al. 2002; Quirk 2007; Bravo 2011; Bales 2012). Many authors have described the trade in human beings as being so entrenched within our societies that it is in fact "hidden in plain sight" (see Newton, Mulcahy, and Martin 2008; Hepburn and Simon 2010). With globalization, travel across the globe is now relatively easy and it is much, much cheaper to acquire and maintain individuals within the industry. Sex traffickers have reduced human life to an item that can be bought, sold and disposed of when its value diminishes (Bales 2012).

This research has found that Belize's sex industry is growing exponentially, that there are copious numbers of accessible, vulnerable women in neighboring Central American countries, corrupt authorities, low investment costs, and that with an expanding tourism sector, there has also been a steady increase in well-paying clientèle (see Cohen and Felson 1979; Kenyon and Schanz 2014). The trafficking process itself appears to be simple when compared to the processes often described in the literature.

There is a general paucity of research surrounding sex trafficking despite its increasing relevance; this paper focuses on the thematic network analysis of transcribed data obtained from interviewing individuals actively involved within the sex industry in Belize: sex workers, traffickers, clients and relevant officials. According to Attride-Stirling (2001) "if qualitative research is to yield meaningful and useful results, it is imperative that the material under scrutiny is analysed in a methodological manner, but unfortunately there is a regrettable lack of tools available to facilitate this task" (Attride-Stirling 2001, p. 386).

Criminological research has commonly focused on single-group, single-site analysis (see, for example, Cockbain, Brayley, and Sullivan 2014; Laczko 2014; Bishop 2016; Elmes et al. 2017). This current research significantly contributes towards filling this knowledge gap through not only examining four distinct groups but also in taking a multiple-site approach, since the research participants were from many different parts throughout Belize, specifically: Belize City, Cayo, Belmopan, San Ignacio, Melchor and San Pedro. This approach has led to a successful extrapolation of Attride-Stirling's (2001) method through creating an additional level of analysis. The emergence of what I term a supra-global theme encompasses the realities of the sex industry in Belize from the perspectives of all participants. Importantly, AttrideStirling's (2001) thematic network analysis has not been altered, but advanced to accommodate more expansive levels of research.

\section{SEX TRAFFICKING IN THE 21ST CENTURY: THE “BIG BUSINESS" OF SLAVERY}

The trafficking in human beings has been identified as the third most lucrative industry globally with between one and two million people being trafficked each year and is closely linked to the arms and ammunitions trade and the trade in narcotics (Seelke 2010). Human trafficking is distinguishable from human smuggling and sex work; it has been defined as the "illegal trade in human beings through abduction, the use of threat or force, deception, fraud or sale for the purposes of sexual exploitation or forced labour" (Bernat and Zhilina 2010, pp. 2-3). It is often depicted as the modern-day version of the trans-Atlantic slave trade, with Bales (2012) aptly describing our reality when he stated "for thousands of years people have been enslaved...but slavery has never disappeared; instead, it took on a different form" 
(p. 12). Today, trafficking networks are portrayed as sophisticated and complex entities characterized by a multi-million dollar industry. Jayson (2013) stated that "along with drugs and weapons, it is now believed to be one of the leading sources of income for criminal organizations" (p. 3).

The term "trafficking" is often synonymous with a range of activities including human smuggling, drug trafficking, trafficking for forced labor and child trafficking, to name just a few. Sex trafficking is a major component of human trafficking and occurs when "a person is coerced, forced or deceived into prostitution, or maintained in prostitution through coercion...all those involved in recruiting, transporting, harbouring, receiving or obtaining the person for that purpose have committed a trafficking crime. Sex trafficking can also occur alongside debt bondage" (United States Department of State 2009, pp. 21-2).

Worldwide, every country is affected by human trafficking to some degree. Many authors (see Bales 2004; Obokata 2006; Aronowitz 2009; Shelley 2010; Van der Wilt 2014) have argued that sex trafficking is a crime against humanity since it deprives individuals of their freedom, rights and well-being, reducing them to articles to be bought, sold and traded on the sex market. Trafficking for sexual exploitation, based on market demand, especially relates to women and children (with boys to a lesser degree) and is in actuality less challenging than smuggling drugs, trading arms or laundering money. It is an industry characterized by a dichotomy of high rewards and low risks. In terms of its profitability, one should keep in mind that trafficking is highly lucrative "because human beings can be sold over and over, unlike drugs which are sold and consumed. Also, in trafficking, the victims run the risk of being caught and prosecuted, not the traffickers who control them" (Jayson 2013, pp. 4-5).

Jayson (2013) further emphasized this point when she stated that "a person trafficked into prostitution will usually earn the trafficker 8 to 10 times more than a non-trafficked prostitute...trafficked prostitutes are considered property. As property, they receive little or no pay and can be traded or sold to another trafficker or brothel at any time" (Jayson 2013, p. 13).

Kara (2009) asserted that sex trafficking had two distinguishable components: slave trading and slavery. On one hand, slave trading was described as the process of "acquiring, recruiting, receiving or transporting an individual, through any means and for any distance, into conditions of slavery or slave-like exploitation." On the other hand, slavery was described as the "process of coercing...services from a captive individual, through any means" (Kara 2009, p. 5). Sex trafficking is geared towards maximizing profits, with slave trading characterizing the supply side of the market while slavery accounts for the demand side of the equilibrium. It generates billions of dollars annually at a profit margin that is higher than almost any business in the world, illicit or otherwise, with "one woman or child...trafficked for the purpose of sexual exploitation every sixty seconds" (Kara 2009, p. 17). This industry is "akin to a multinational corporation that has achieved steady-growth and produces immense cash flows" (Kara 2009, p. 23). To better understand what is meant by immense cash flows an example can better illustrate. Japan for instance, has the world's second largest economy with the sex trade accounting for about $\$ 400$ million dollars per year while exploiters in Ukraine earn more from trafficked women in a week than the country's law enforcement annual budget (Okereke 2005).

In distinguishing between modern-day slavery and the trans-Atlantic slave trade, Sigmon (2008) concluded that "holding people in slave-like conditions is far more 
profitable today than it was when the sale of human beings was conducted in open markets and slaveholders invested relatively large sums of money to buy and legally own people...victims of modern day slavery are not legally owned but are controlled through coercion, threats and violence" (p. 245).

This is reflective of Bales (2012) who wrote that trafficked people in the 21st century are considerably less valuable, they are now disposable, easily replaceable and cheap. He stated that "slavery is a booming business and the number of slaves is increasing. People get rich by using slaves. And when they've finished with their slaves, they just throw these people away. This is the new slavery which focuses on big profits and cheap lives" (Bales 2012, p. 246).

\section{SEX TRAFFICKING IN BELIZE}

Belize is considered to be a Central American as well as Caribbean nation and continues to successfully maintain relations with both regions. Geographically, Belize is recognized as a transit country en route to Mexico and eventually the United States since there are several border points where anyone can cross without going through security controls (Petit 2004). Migration is essentially a way of life in Central America and given Belize's proximity to other countries and the Caribbean Sea, it is a major trafficking hub.

The majority of trafficked victims in Belize come from Honduras, El Salvador, Guatemala and Mexico and are trafficked for sexual exploitation. Bar and brothel owners in Belize often contract with traffickers to acquire women from these other countries. In many instances, traffickers are also bar owners. There are also instances of internal sexual exploitation involving minors in what is locally termed the "sugar-daddy phenomenon." This involves older men having sexual relations with teenage girls, often with their parents' knowledge, in exchange for money, groceries or gifts (Petit 2004).

The Belizean sex industry is highly exploitative; many sex workers operate under deplorable working conditions and with low remuneration in comparison to other places where working conditions and incomes are comparably better such as in Campo Alegre in Curacao (Campo Alegre 2016). In Curacao, the sex industry is regularized; sex worker positions, worker benefits and services rendered are advertised publicly (Kempadoo 2004). These women remain in Belize because the money earned far exceeds what they would have earned in their own countries with the state, business owners, police and immigration officers, taxi drivers and so forth benefiting from their sexual exploitation. In the face of this reality, the sex trade remains a viable economic activity and continues to successfully operate throughout the country.

\section{METHODOLOGY}

In adherence to a constructivist framework, this paper is based on the belief that to achieve knowledge it is necessary to examine the ways in which knowledgeable subjects describe their own realities. Holstein and Gubrium (2008) summed up this approach when they stated that "knowledgeable is plural and fallible, and conversations and social interactions are the ultimate contexts in which knowledge is produced and understood" (p. 432).

Four distinct groups of research participants which included specifically sex workers, traffickers, clients and knowledgeable local officials were interviewed. 
This research employed an emic-oriented, qualitative approach which facilitated the use of semi-structured interviews geared at understanding the world from the participants' lived experiences and knowledge. A good definition of the term "emic" comes from Yin (2015, p. 11) who noted that "an emic perspective attempts to capture indigenous meanings of real-world events.” Willis and Jost (2007) provided added clarification when they stated that such an approach involved looking "at things through the eyes of members of the culture being studied" (p. 100). The data were gathered in Belize from January 2014 to October 2014 and, unlike the large sample sizes employed in quantitative research, this study encompassed 16 sex workers, four traffickers, four clients and 10 relevant officials.

These small sample sizes are a reflection of the reality corroborated by many researchers who describe research on human trafficking as being "difficult" at best. This is primarily because the populations are "hidden" (see Cwikel and Hoban 2005; Miller 2008; Hepburn and Simon 2010). Heckathorn (1997) described these hidden populations as being characteristically unwilling to cooperate or participate in research activities because they are involved in activities generally accepted as illegal or clandestine. Jayson (2013, p. 5) explained this further with regards to the sex trade; stating that "the involvement of the individual in criminal activity makes them both a criminal and a victim at the same time." Heckathorn (1997) added that there is also no guiding sampling frame; in other words, there is no representation of the size of the group being studied or the conditions which define the group. The intention of this research was not particularly focused on quantifying the number of participants, but instead was aimed at attaining a substantial understanding of the realities of those involved in the sex trade in Belize, through detailed interviews with accessible, informed and relevant participants.

\section{THEMATIC NETWORK ANALYSIS}

LeCompte and Schensul (1999) defined analysis as the "process a researcher uses to reduce data to a story and its interpretation" (Kawulich 2004, p. 4). Attride-Stirling's (2001) thematic network analysis allows for the organization and analysis of both content and discourse as they emerge from raw text. The process seeks to unearth significant themes in a text at different levels whilst simultaneously providing structure and allowing for an interpretation of the data. Simply stated, this approach involves the selection of key words or codes emerging throughout the data; these codes are then grouped into clusters of similar terms. Attride-Stirling's approach employs three levels of analysis: basic themes, organizing themes and global themes. The thematic network is developed initially from the creation of basic themes and illustratively, it moves inwards towards a global theme. Basic themes are firstly classified according to the underlying story being told into organizing themes. These organizing themes are now reinterpreted in light of their basic themes, and are brought together into one super-ordinate theme or the global theme.

- Basic themes: these are the most basic emergent themes and are determined from the data. These are simple premises characteristic of the data and say very little on their own. To make sense beyond their immediate meaning, basic themes need to be considered within the context of other basic themes; this leads to the emergence of organizing themes. 


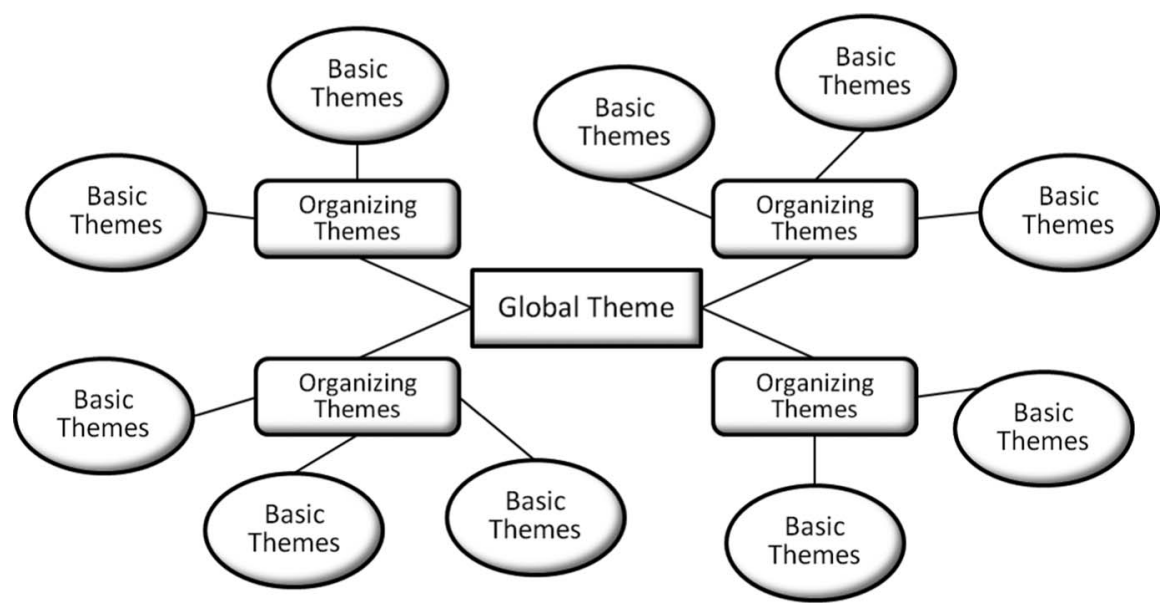

Figure 1. Thematic Network Analysis

Source: adapted from Attride-Stirling (2001, p. 388).

- Organizing themes: these are middle-order emergent themes that organize basic themes into clusters of similar issues and reveal more about the data at the mezzo level.

- Global themes: these are super-ordinate themes which summarize and make sense of the clusters derived from the organizing themes (Attride-Stirling 2001) (see Figure 1).

Thematic networks are presented as web-like structures; there is no hierarchy but instead the inter-relationships among the groups are better illustrated. These networks are tools of analysis and not the analysis per se. Importantly, after a thematic network has been constructed, its purpose is to serve as an organizing and illustrative tool in the interpretation of the text.

Attride-Stirling describes in detail her six-stage approach to creating the network(s) in Figure 2 which is applied to the following section.

\section{APPLYING THEMATIC NETWORK ANALYSIS TO THE INTERVIEW DATA}

The application of a thematic network is simply a way of organizing a thematic analysis of qualitative or transcribed textual data into meaningful themes that describe the phenomenon being investigated. This process of developing themes from textual data and using illustrative representations is well established within qualitative research. Attride-Stirling's (2001) thematic network analysis, which she described as "not in any way a new method," was successfully applied (p. 338). The data were initially coded through identifying and selecting specific words or topics that were common throughout the interviews; the transcribed data were grouped into four individual categories: traffickers, sex workers, clients and officials. Coding facilitated the extraction of themes and "the identification of underlying patterns and structures" ... which were "specific enough to pertain to one idea, but broad enough to find incarnations in various different text segments." Similar themes are then arranged into smaller groups and "these groupings will become thematic networks" (Attride-Stirling 2001, p. 392). 
ANALYSIS STAGE A: REDUCTION OR BREAKDOWN OF TEXT

Step 1. Code Material

(a) Devise a coding framework

(b) Dissect text into text segments using the coding framework

Step 2. Identify Themes

(a) Abstract themes from coded text segments

(b) Refine themes

Step 3. Construct Thematic Networks
(a) Arrange themes
(b) Select basic themes
(c) Rearrange into organizing themes
(d) Deduce global theme(s)
(e) Illustrate as thematic network(s)
(f) Verify and refine the network(s)

ANALYSIS STAGE B: EXPLORATION OF TEXT

Step 4. Describe and Explore Thematic Networks

(a) Describe the network

(b) Explore the network

Step 5. Summarize Thematic Networks

ANALYSIS STAGE C: INTEGRATION OF EXPLORATION

Step 6. Interpret Patterns

Figure 2. The Six Steps of Attride-Stirling's (2001) Thematic Network Analysis Source: adapted from Attride-Sterling (2001, p. 391).

The construction of networks involved firstly the selection of basic themes; this is simply the renaming of the original themes from the text, allowing for a "conceptual division between the identification of themes and the creation of thematic networks" (Attride-Stirling 2001, p. 392). These basic themes were then further clustered based on larger shared ideas, into organizing themes. A further analysis of the organizing themes, taking into consideration that basic themes summarize the main assumptions of the organizing themes, allowed for the creation of four distinct global themes for each group of research participants. Based on Attride-Stirling's (2001) work, the global theme encapsulates the main part in the text and, thus, reflects the prevalent assumptions throughout the data. The thematic networks were identified, then described and explored in detail using various excerpts from the transcribed data to provide support for the themes identified.

\section{METHODOLOGICAL INNOVATION}

\section{Advancement of Attride-Stirling's (2001) Thematic Network Analysis}

As mentioned earlier, Attride-Stirling's (2001) thematic network analysis has been effectively applied to single-group, single-site studies (see Figure 3; Cockbain et al. 2014; Bishop 2016), and since many researchers do not study multiple groups or multiple sites, thematic network analysis has proven itself to be an effective analytical tool for qualitative researchers. Because this research involved data from four groups, in various locations, it led to the extrapolation of the application of thematic network analysis from a single-group, single-site analysis, to multiple groups and multiple research sites.

As discussed, the application of thematic network analysis to the data has resulted in the emergence of four global themes, each specific to a particular group, namely: sex traffickers, sex workers, clients and officials, each with its own global theme. 


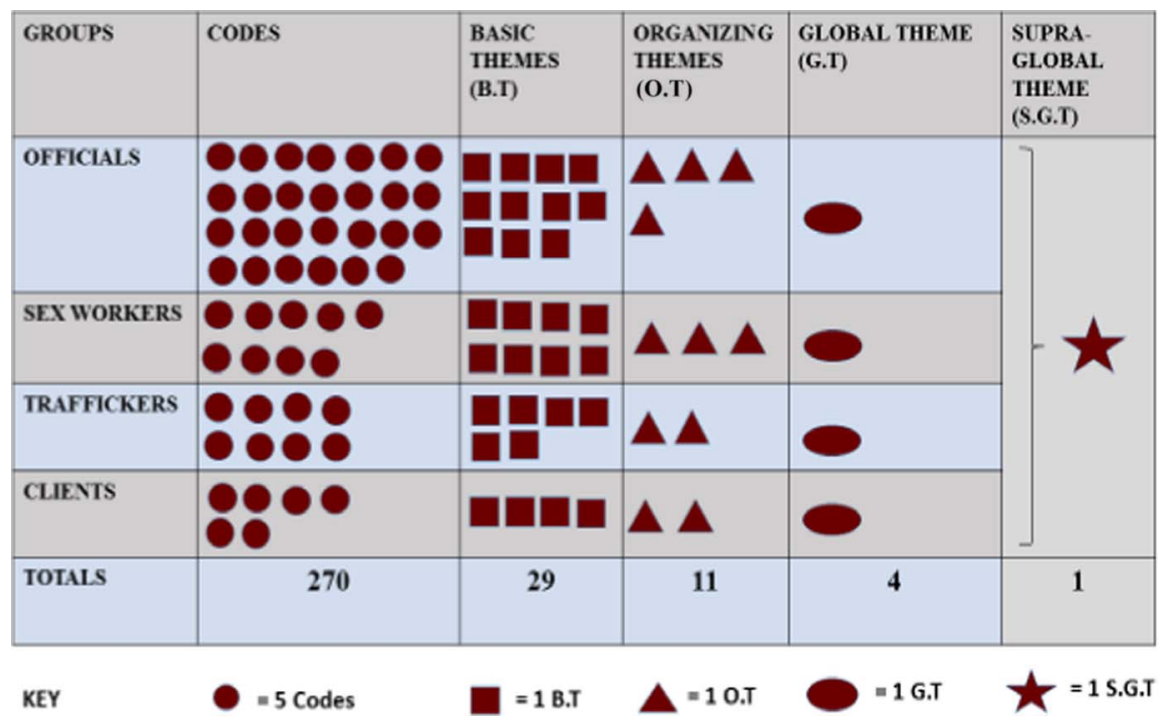

Figure 3. Applying Thematic Network Analysis to the Data

Although these global themes provided a relevant and comprehensive account of sex trafficking and sex work in Belize, a single emergent theme reflective of the data in general was desired. The rationale was that the analysis thus far, although informative, lacked the ability to provide an understanding of sex trafficking based on the perspectives from all four groups investigated; here lies the methodological innovation. With the continued understanding that organizing themes summarize the main assumptions of the global theme, the four global themes were treated and analyzed as a second group of organizing themes from which a single supra-global theme now emerged (see Table 1). This new supra-global theme not only successfully encapsulated the perspectives of all groups but retained the significance of the contributions made by each group of participants. Figure 4 illustrates this thematic network analysis with the inclusion of the supra-global theme.

\section{INTERPRETATION OF EMERGENT PATTERNS: EXPLORING THE NEXUS AMONG GROUPS AND THE SIGNIFICANCE OF THE SUPRA-GLOBAL THEME}

\section{Sex Traffickers}

The views expressed by traffickers were categorized by the global theme: human networks as part of the Belizean sex industry. Four traffickers were interviewed. Given the nature of their operations and their distrust towards outsiders, such a low participatory rate was expected. It was generally agreed that corrupt officials are an integral component in facilitating the trafficking process, making it relatively simple to bring women across the border to the local bars. These women earn money through sex work and fichera, which is the local term for tokens earned from drinks purchased for the women by patrons and clients. Their drinks would usually cost double, sometimes triple the regular price. Substantial parts of their earnings were tangled in debts to the trafficker. These practices are common to many bars and sex clubs worldwide. 
Table 1. The Four Levels of Analysis

\begin{tabular}{|c|c|c|c|c|}
\hline $\begin{array}{l}\text { Groups } \\
\text { examined }\end{array}$ & Basic themes & Organizing themes & Global themes & Supra-global theme \\
\hline Traffickers & $\begin{array}{l}\text { Elements of sex trafficking } \\
\text { Corruption } \\
\text { Recruitment } \\
\text { Other traffickers } \\
\text { Sex workers } \\
\text { Clients }\end{array}$ & $\begin{array}{l}\text { Characteristics of sex trafficking } \\
\text { Groups }\end{array}$ & $\begin{array}{l}\text { Human networks as } \\
\text { part of the Belizean } \\
\text { sex industry }\end{array}$ & $\begin{array}{l}\text { The proliferation of sex trafficking and sex } \\
\text { work in Belize }\end{array}$ \\
\hline Sex workers & $\begin{array}{l}\text { Elements of sex work } \\
\text { Root causes of sex trade } \\
\text { Sex workers } \\
\text { Perceptions of sex work } \\
\text { Expectations for a better life } \\
\text { Leaving sex work } \\
\text { Employment } \\
\text { Bars } \\
\text { Transportation }\end{array}$ & $\begin{array}{l}\text { Root causes and the inherent nature of } \\
\text { sex work } \\
\text { Societal perceptions of sex work } \\
\text { Seeking sex work }\end{array}$ & $\begin{array}{l}\text { Societal perceptions of the } \\
\text { elements } \\
\text { of sex work and sex } \\
\text { workers }\end{array}$ & $\begin{array}{l}\text { The proliferation of sex trafficking and sex } \\
\text { work in Belize }\end{array}$ \\
\hline Clients & $\begin{array}{l}\text { Types of clients } \\
\text { Interests of clients } \\
\text { Description of sex workers } \\
\text { Knowledge of sex workers' lives }\end{array}$ & $\begin{array}{l}\text { Description of clients } \\
\text { Clients' perceptions of sex workers }\end{array}$ & $\begin{array}{l}\text { Motivation for sex } \\
\text { consumerism }\end{array}$ & $\begin{array}{l}\text { The proliferation of sex trafficking and sex } \\
\text { work in Belize }\end{array}$ \\
\hline Officials & $\begin{array}{l}\text { Root causes } \\
\text { Culture } \\
\text { Corruption } \\
\text { Legislative and social strategies } \\
\text { Traffickers } \\
\text { Recruiters } \\
\text { Victims } \\
\text { Clients }\end{array}$ & $\begin{array}{l}\text { Root causes and the perpetuation of the } \\
\text { sex trade } \\
\text { Social and legislative framework } \\
\text { Groups involved }\end{array}$ & $\begin{array}{l}\text { The proliferation of sex } \\
\text { trafficking }\end{array}$ & $\begin{array}{l}\text { The proliferation of sex trafficking and sex } \\
\text { work in Belize }\end{array}$ \\
\hline
\end{tabular}

Employment

otivation for sex

proliferation of sex trafficking and sex 


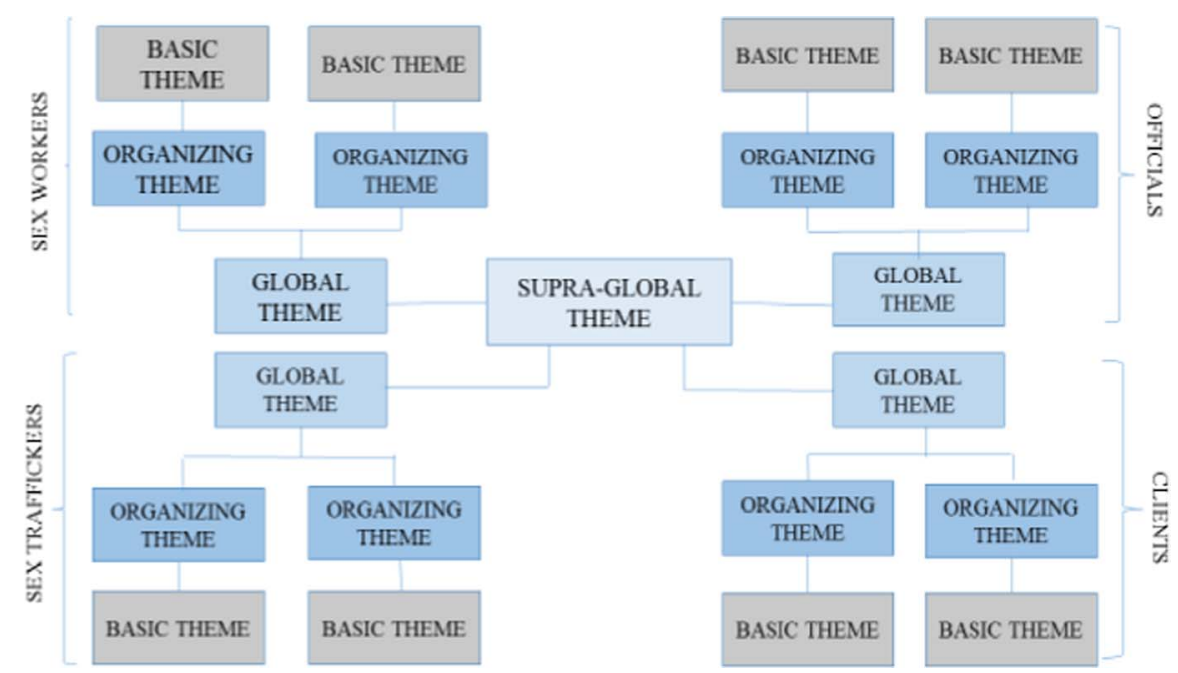

Figure 4. Thematic Networks: The Creation of the Supra-Global Theme: Basic Themes - Organizing Themes Global Themes - Supra-Global Theme

The sex industry was portrayed as being primarily a business operation with measurable profits and losses, involving significant amounts of money with relatively little or no risk to the trafficker. Obtaining women to work in the sex trade was described as a somewhat simplistic process often carried through by the trafficker themselves. In describing the women who worked for them, it was stated that they often sent money to their families, they came from poor socio-economic situations, were young, attractive and of Spanish descent, and mainly from Guatemala and Honduras. Some have boyfriends who assisted them financially. It was also stated that these women were sex workers in their own countries prior to their arrival in Belize. One particular trafficker who was interviewed emphatically stated, "Here, you call them fresh meat but over there they are old beef because the same thing they do over there that's why they come here, to do the same thing." This is significant since it demonstrates the further exploitation of an already highly vulnerable group.

They identified clients as wealthy men or foreigners, particularly tourists and retirees or local businessmen. Generally, a client is anyone who can pay for the services desired. They explained that clients were interested in relaxing, having drinks and being with the women. Some insight about other traffickers was also offered. There were no risks involved and profits were substantially high (see Figure 5).

\section{Sex Workers}

The global theme societal perceptions of the elements of sex work and sex workers reflected the views of the 16 sex workers from seven different bars located in four districts: Belize City, Cayo, Belmopan and San Pedro. Several components of sex work were discussed including sexual health, false promises, having familial obligations, distrust towards authorities and fichera.

Sex workers talked about the reasons which led to them becoming involved in sex work including poverty, lack of alternative income-earning opportunities, having 


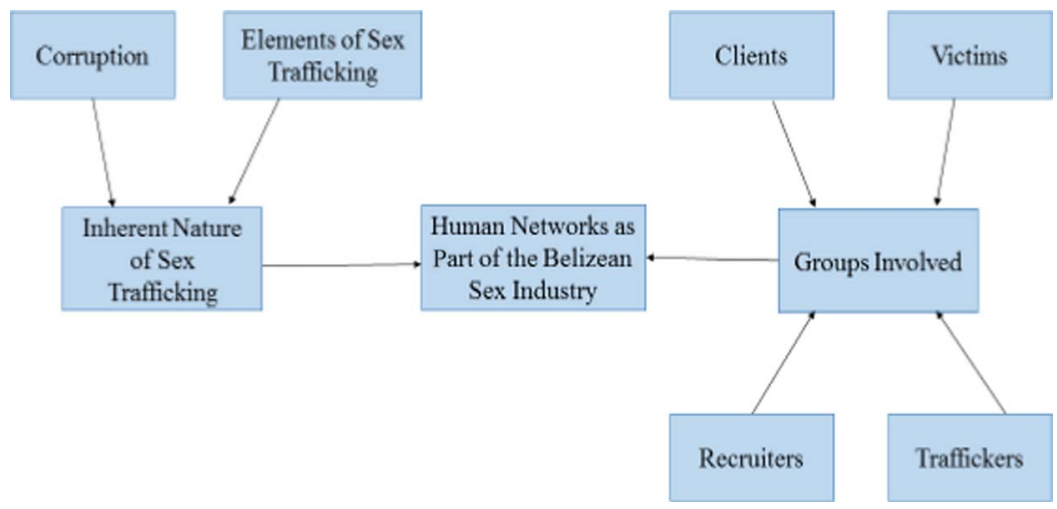

Figure 5. Thematic Network: Sex Traffickers

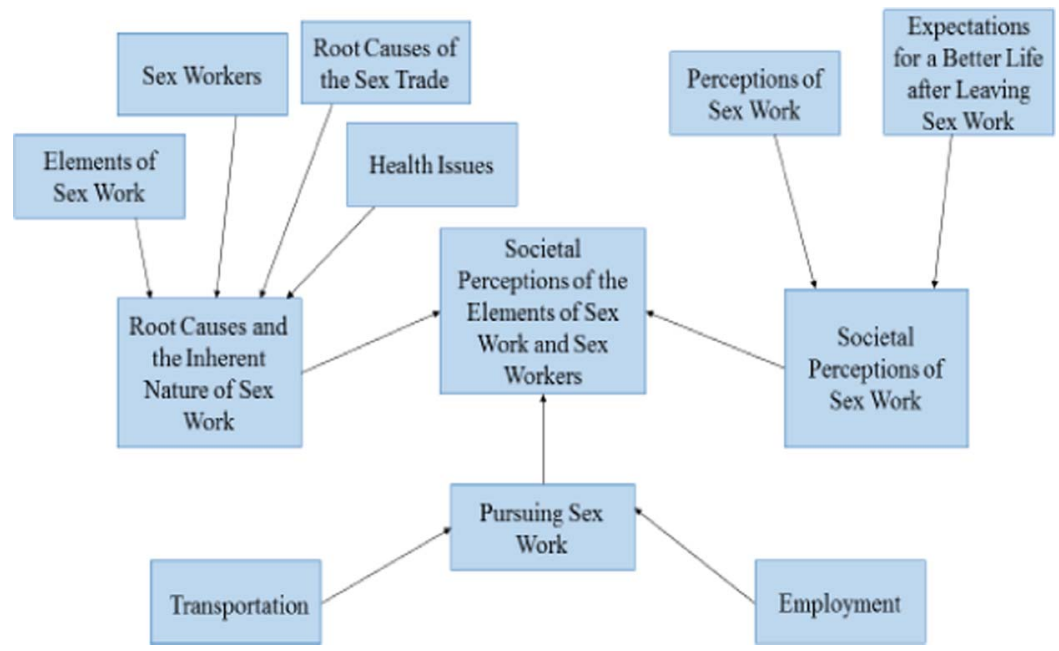

Figure 6. Thematic Network: Sex Workers

dependants, being single mothers, the stigma attached to sex work and experiences with abusive relationships. These women generally expressed the view that sex work was easy work and, for many, was the best alternative they had to acquire at least some means of financial stability. They stated that having sex with clients was meaningless and most expressed hopes of leaving the industry and adopting mundane roles as babysitters, fast food proprietors and seamstresses (see Figure 6).

\section{Clients}

Four clients were interviewed; these interviews were based on the chance a patron was interested in talking. In general, clients were more concerned with drinking, talking with other patrons or with the women working there. The global theme derived from the thematic analysis was motivations for sex consumerism. 


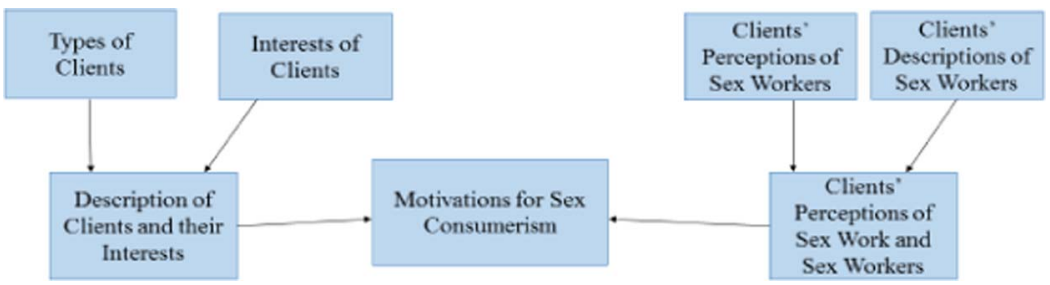

Figure 7. Thematic Network: Clients

Factors such as sexual desire, the need for companionship and the thrill of having a sexual encounter with an "exotic" woman were some of the reasons why men patronized these establishments. The local men tended to have a more personal relationship with some of the women, going so far as to befriend them, helping them financially and giving them emotional support. Clients who were tourists, however, were primarily concerned with purchasing sexual services, reflective of the overall increase in the demand for "sand, sea and sex tourism" (see Kempadoo 1999) (see Figure 7).

\section{Knowledgeable Local Officials}

Ten local officials were interviewed; these individuals came from various government departments such as the police, immigration and human development while others were from autonomous private organizations. The global theme, the proliferation of sex trafficking emerged focusing specifically on contributory factors such as socioeconomic hardships, cultural acceptance and corruption. Sex trafficking was presented as a complex and organized operation, encompassing elements such as border permeability, smuggling, the recruitment of vulnerable women and Belize's geographical proximity to the United States. These factors were largely reflective of the extant literature examined (see Bales 2005; Okereke 2005; Aronowitz 2009; Shelley 2010). Many officials also discussed initiatives being taken to curb trafficking in human beings, offering their own insights into the applicability and success of those programs.

The sex industry has a substantial presence within Belizean society and based on the views expressed by the officials, the industry will continue to develop exponentially. There is no shortage of sex workers from neighboring Central American countries; and the clientèle base has been increasing steadily, coinciding with the growth of the tourism sector. Additional factors including punitive sanctions against traffickers, poor law enforcement efforts, porous border lines and corruption within the public sector were also identified (see Figure 8).

\section{The Supra-Global Theme: Inter-relationships among Global Themes}

These four global themes are combined and analyzed to create the supra-global theme: the proliferation of sex trafficking and sex work in Belize. There is a prominent advancement in the relevance, applicability and general understanding of the data since the supra-global theme offers insight into the Belizean sex industry through a combined lens. It has explained in detail the inherent nature of the Belizean sex industry, societal perceptions of sex work, the proliferation of the sex trade and the 


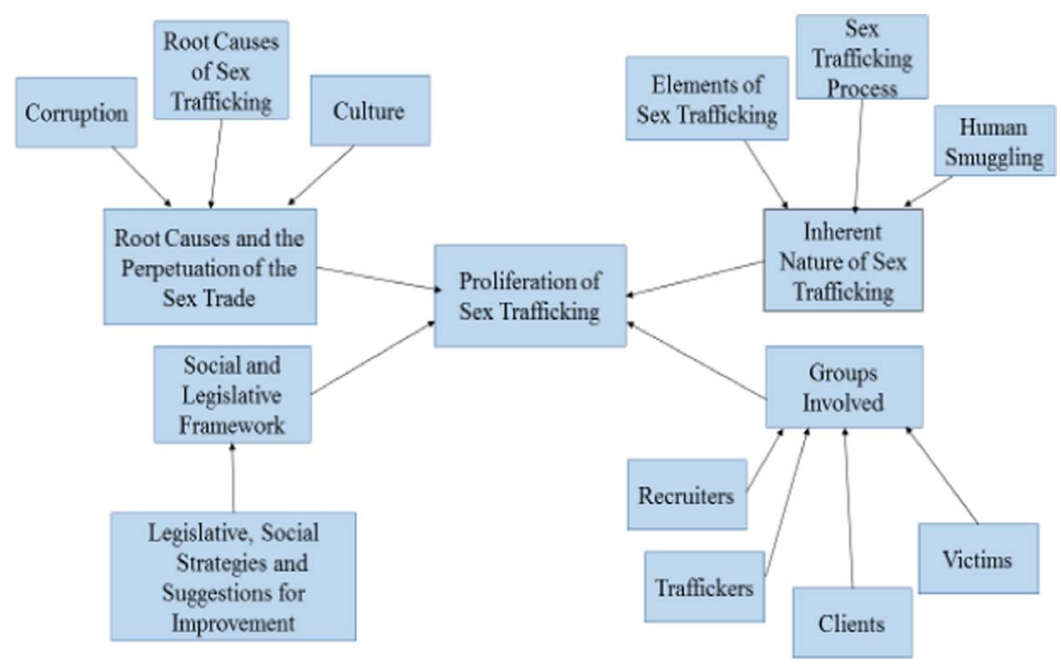

Figure 8. Thematic Network: Officials

significance of the human networks involved. Figure 9 illustrates the visualization of the thematic network with the inclusion of the supra-global theme.

Although the four groups examined are distinct, the analysis of the data demonstrated several linkages among them, making the emergent supra-global theme even more relevant (see Figure 10). Sex workers and traffickers, for example, both offered insights into the sex industry, discussing to some extent the characteristics of sex work, factors which perpetuate the trade and the general societal perceptions of sex workers. In regards to societal perceptions, clients and officials also shared their insights. Commonly stated causal factors identified included poverty, familial obligations, and the desire for economic stability, corrupt authorities and porous border controls. Additional issues identified such as stigmatization, a lack of alternative income-earning opportunities as well as a general belief that sex work is "fast, easy money" were believed to have significantly contributed to the industry's growth.

Data from sex workers and officials pointed to high migration rates as a significant cause for concern. Given the high numbers of migrant women entering Belize in search of work there is no shortage of exploitable women and, with the poverty and social unrest characteristic of many Central American countries, it was stated that such trends will continue. These women often seek employment for themselves at bars.

Belize's economy is developing and its tourist sector is simultaneously expanding to embrace the trend of "vacation sex." Traffickers and clients in particular described such clientèle as being wealthy men, either local businessmen and government officials or tourists. Sex workers then thrive on being unofficial "tourist attractions;" to many foreigners these women are "exotic," readily available and affordable.

\section{Justifying an Innovative Analytical Approach}

Attride-Stirling's (2001) thematic network analysis has been successfully applied in this study. Four distinct groups of participants were examined, and the application of thematic network analysis as originally posited resulted in the emergence of four 


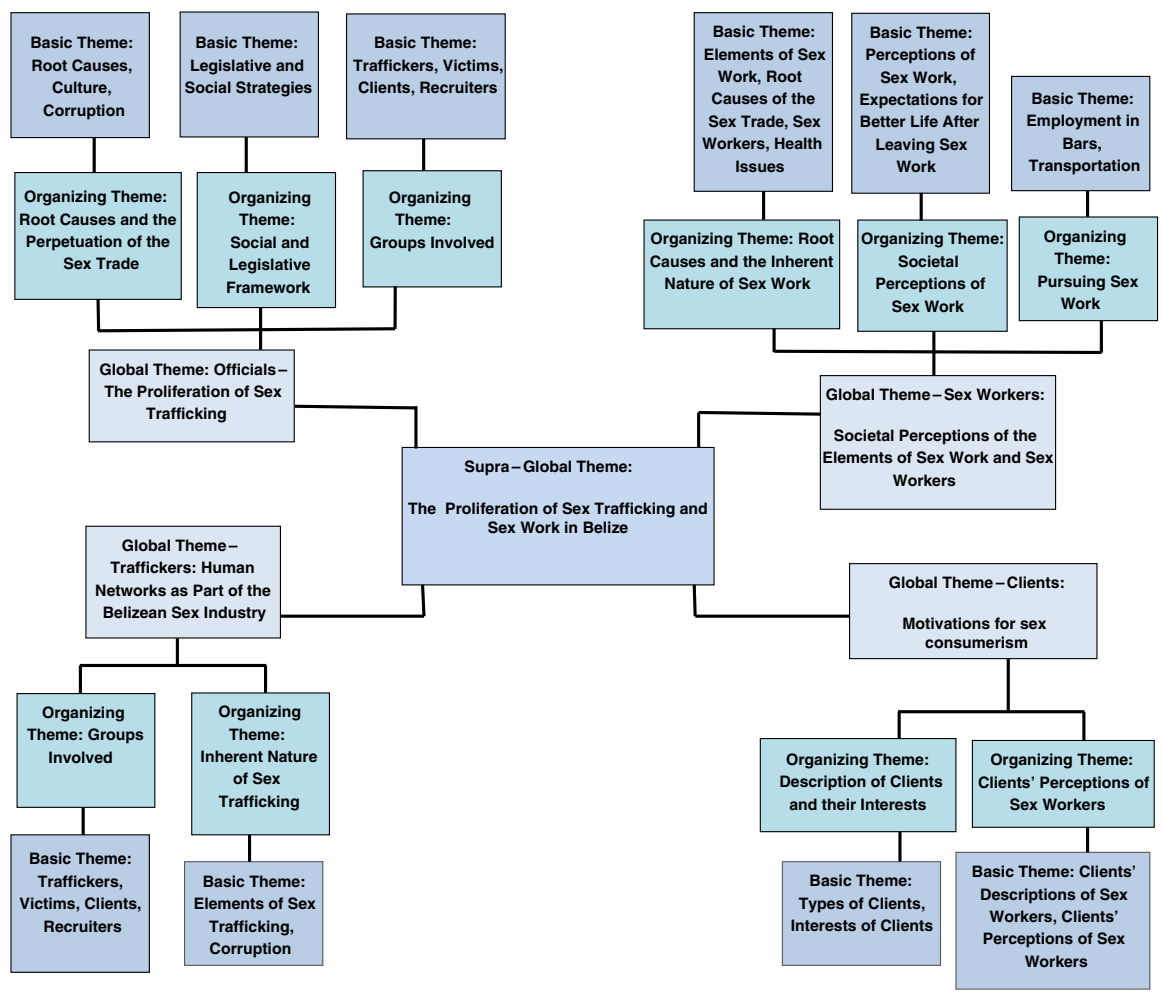

Figure 9. Visualization of the Thematic Network with the Inclusion of the Supra-Global Theme

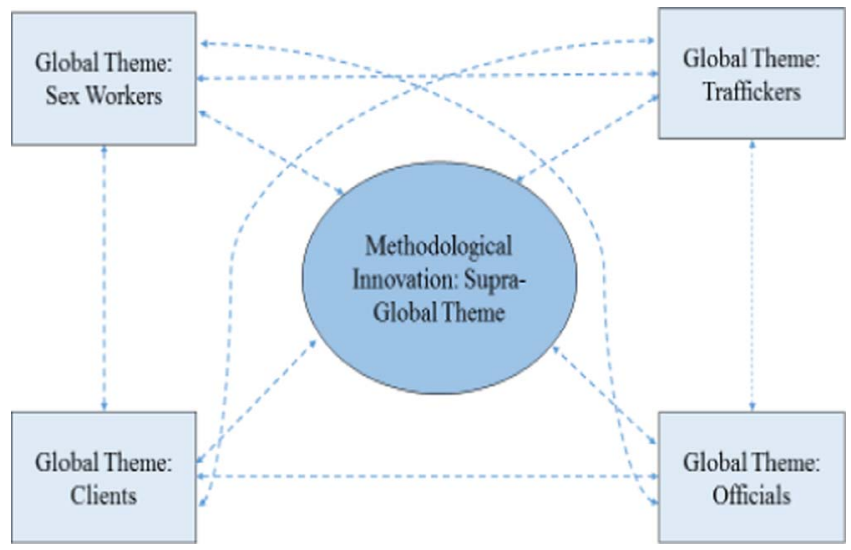

Figure 10. The Nexus: Inter-relationships among Groups

global themes. This led to an extrapolation of the method to combine the global themes into a distinct supra-global theme.

The questions now arise, why was such methodological advancement necessary and/ or did it actually enhance thematic network analysis? This can be answered through 
exploring three possible alternatives. One alternative would be to combine all the basic codes for all four groups examined and to generate one large analysis. This would have considerably reduced the overall relevance of the research since the significance of what was said and by whom would have been lost for each group of participants.

Another option would have been to combine all the organizing themes for all four groups to create one emergent global theme, stopping the analysis there. This method could have also been used, but doing so would have reduced the integrity of the analysis since it would have effectively excluded the themes which would have emerged from combining the four global themes.

A third alternative would have been to stop the analysis with the emergence of the four global themes (one from each group) and explain the Belizean reality from the perspectives of each group studied. This has been the approach adopted in other studies where there were multiple global themes. These alternative approaches would not have provided the holistic understanding into the sex trade that was desired. Based on the intersections described earlier, it is clear that to examine each global theme separately would have reduced the overall relevance of the research. To obtain the desired result, creating a new level of analysis was considered the best methodological route.

Importantly, Attride-Stirling's (2001) basic thematic network analysis has not been altered. Instead it was advanced to accommodate research that is more expansive as well as offers opportunities to enhance future research through analyzing not only multiple groups but comparing multiple sites. This approach can thus lead to an even further development of thematic network analysis through examining multiple sites, each with their own supra-global themes, into a higher level of analysis beyond that which has been described here, to encompass the perceptions of all groups and locations examined.

The innovation of Attride-Stirling's (2001) thematic network analysis presented here has created a good opportunity for future methodological advancement. The current research has examined multiple groups in multiple sites throughout Belize. If similar research is conducted in other countries, the emergent supra-global theme for each country can be treated as another group of organizing themes from which to form another level of analysis, the emergence of a higher level of supra-global theme. This can heighten the relevance of the findings to a particular region and can therefore better inform pertinent regional and international policies.

Such methodological development then addresses the need within qualitative research for greater levels of disclosure and the development of tools capable of facilitating such analyses. Attride-Stirling (2001) in presenting her method of analysis also expressed the need for continued developments in qualitative research in order to maintain a "learned and robust methodology" (Attride-Stirling 2001, p. 386). She also maintained that this can be achieved through "recording, systematizing and disclosing our methods of analysis, so that existing techniques may be shared and improved, and new and better tools may be developed" (Attride-Stirling 2001, p. 386).

\section{CONCLUSION}

This article explored the methodological advancement of Attride-Stirling's (2001) thematic network analysis technique. Detailed interviews were conducted with four major groups, specifically traffickers, sex workers, clients and government/nongovernment officials. From the analysis of these interviews, four global themes 
emerged. These global themes were human networks as part of the Belizean sex industry, societal perceptions of the elements of sex work and sex workers, motivations for sex consumerism and the proliferation of sex trafficking.

Traffickers described sex trafficking as a simplistic process, often involving just one individual, usually the trafficker themselves. They described a reality characterized by the involvement of corrupt public officials, the relative ease of recruiting and transporting sex workers and a favourable market with an increasing clientèle. The sex workers interviewed did not consider themselves victims. Despite having to work under deplorable conditions, receiving little pay and being indebted to the bar owners, they regarded themselves as being gainfully employed. Issues such as poverty, lack of alternative opportunities, social stigma and cultural attitudes towards sex work emerged.

Clients, ranging from wealthy businessmen to daily-paid laborers, maintain the demand for paid sex. Many tourists now want to experience "vacation sex" and Belize is no exception. Establishments providing sexual services operate in plain sight throughout Belize and are easily accessible to the public. Officials focused particularly on causal factors, identifying issues including poverty, abuse and the desire for a better life. The issue of corruption was the main focus for many of the officials since they considered corruption to be a vital component in the overall success of the Belizean sex industry. They, however, contrary to the traffickers interviewed, described the Belizean sex trade as a complex, highly organized crime, a description commonly found in the existing literature.

Each global theme explained sex trafficking and sex work in Belize to some extent, but did not provide the in-depth, holistic understanding desired. The overall intention was to achieve an understanding of Belize's sex industry which reflected the main perceptions of all the groups examined. Attride-Stirlings's (2001) analytical technique was taken a step further and explored the inter-relationships among these four emergent global themes to create a supra-global theme. This allowed not only for a more relevant and holistic understanding but simultaneously retained an appreciation of the perspectives offered by the individual groups. The supra-global theme is significant methodologically, offering a new level of analysis which can accommodate future research that is more expansive or complex. It is also significant in regards to developing a more accurate understanding into the phenomena being studied.

To explore the sex industry solely from one perspective, as much of the existing literature has done, now appears to be biased and of such a limited focus that it does not appear to have adequate veracity. The issues surrounding the sex trade can best be appreciated when multiple perspectives are considered. The supra-global theme presented here, "the proliferation of sex trafficking and sex work in Belize," describes a reality where Belize's sex industry is maintained and encouraged by corrupt, profitseeking human networks, the stigmatization of sex workers, cultural acceptance and poverty coupled with a lack of alternative income-generating opportunities. These factors all perpetuate the supply side of the sex market equilibrium while the demand side is characterized by increasing clientèle numbers through sex tourism as well as heightened interest by foreign retirees.

From this standpoint, the sex trade in Belize is a developing industry and, because of the several contributory factors described in this paper, the industry will more than likely continue to develop in both scope and magnitude in the future, especially given the belief that these women are no longer "old beef but new meat" in the Belizean context of sex trafficking. 


\section{References}

Aronowitz, Alexis A. 2009. Human Trafficking, Human Misery: The Global Trade in Human Beings. Westport, CT: Greenwood Publishing Group.

Attride-Stirling, Jennifer. 2001. "Thematic Networks: An Analytic Tool for Qualitative Research." Qualitative Research 1(3):385-405.

Bales, Kevin. 2005. Understanding Global Slavery: A Reader. Berkeley, CA: University of California Press.

Bales, Kevin. 2012. Disposable People: New Slavery in the Global Economy. Berkeley, CA: University of California Press.

Bales, Kevin B. 2004. New Slavery: A Reference Handbook. Santa Barbara, CA: ABC-CLIO.

Bernat, Frances P. and Tatyana Zhilina. 2010. "Human Trafficking: The Local Becomes Global.” Women and Criminal Justice 20(1-2):2-9.

Bishop, Kelsey. 2016. "Human Sex Trafficking: A Thematic Analysis of New York Times Coverage." Scientia et Humanitas 6:115-38.

Bravo, Karen E. 2011. "The Role of the Transatlantic Slave Trade in Contemporary Anti-Human Trafficking Discourse." Seattle Journal for Social Justice 9(2):555-97.

Campo, Alegre. 2016. "Campo Alegre Adult Club: The Resort." Retrieved October 20, 2017 (www. campoalegresex.com/the-resort.php).

Cockbain, Ella, Helen Brayley, and Joe Sullivan. 2014. "Towards a Common Framework for Assessing the Activity and Associations of Groups Who Sexually Abuse Children." Journal of Sexual Aggression 20(2):156-71.

Cohen, Lawrence E. and Marcus Felson. 1979. "Social Change and Crime Rate Trends: A Routine Activities Approach." American Sociological Review 44(4):588-608.

Cwikel, Julie and Elizabeth Hoban. 2005. "Contentious Issues in Research on Trafficked Women Working in the Sex Industry: Study Design, Ethics, and Methodology.” Journal of Sex Research 42(4):306-16.

Elmes, Jocelyn, Morten Skovdal, Kundai Nhongo, Helen Ward, Catherine Campbell, Timothy B. Hallett, and Simon Gregson. 2017. "A Reconfiguration of the Sex Trade: How Social and Structural Changes in Eastern Zimbabwe Left Women Involved in Sex Work and Transactional Sex More Vulnerable." PLOS ONE 12(2):e0171916.

Heckathorn, Douglas D. 1997. "Respondent-Driven Sampling: A New Approach to the Study of Hidden Populations.” Social Problems 44(2):174-99.

Hepburn, Stephanie and Rita J. Simon. 2010. "Hidden in Plain Sight: Human Trafficking in the United States." Gender Issues 27(1-2):1-26.

Holstein, James A. and Jaber F. Gubrium (editors). 2008. Handbook of Constructionist Research. New York: Guilford Press.

Jayson, Karen G. 2013. Human Trafficking in North Carolina: Human Beings as a Commodity. Raleigh, NC: N.C. Governor's Crime Commission Criminal Justice Analysis Center.

Kara, Siddharth. 2009. Sex Trafficking: Inside the Business of Modern Slavery. New York: Colombia University Press.

Kawulich, Barbara B. 2004. "Data Analysis Techniques in Qualitative Research." Journal of Research in Education 14(1):96-113.

Kempadoo, Kamala (editor). 1999. Sun, Sex, and Gold: Tourism and Sex Work in the Caribbean. Lanham, MD: Rowen and Littlefield.

Kempadoo, Kamala. 2004. Sexing the Caribbean: Gender, Race, and Sexual Labor. New York: Routledge.

Kenyon, Samuel D. and Youngyol Yim Schanz. 2014. "Sex Trafficking: Examining Links to Prostitution and the Routine Activities Theory." International Journal of Criminology and Sociology 3(1):61-76.

Laczko, Kendall L. 2014. Advocates' Perspectives on Decriminalization and Safety Strategies for Female Sex Workers. Saskatchewan, Canada: Faculty of Graduate Studies and Research, University of Regina.

LeCompte, Margaret D. and Jean J. Schensul. 1999. Designing and Conducting Ethnographic Research. Walnut Creek, CA: Alta Mira.

Miller, John R. 2008. "Call it Slavery." The Wilson Quarterly (1976-) 32(3):52-6.

Newton, Phyllis J., Timothy M. Mulcahy, and Susan E. Martin. 2008. "Finding Victims of Human Trafficking." Bethesda, MD: University of Chicago, National Opinion Research Center. Retrieved August 26, 2016 (https://www.ncjrs.gov/pdffiles1/nij/grants/224393.pdf).

Obokata, Tom. 2006. Trafficking of Human Beings from a Human Rights Perspective. Leiden: Martinus Nijhoff Publishers. 
Okereke, Godpower O. 2005. "The International Trade in Human Beings: A Critical Look at the Causal Factors." Crime and Justice International 21(86):4-17.

Petit, Juan Miguel. 2004. Trafficking of Persons in Belize: Preliminary Report. Washington, DC: Organization of American States.

Quirk, Joel. 2007. “Trafficked into Slavery.” Journal of Human Rights 6(2):181-207.

Raymond, Janice G., Jean D’Cunha, Siti Ruhaini Dzuhayatin, H. Patricia Hynes, Zoraida Ramirez Rodriguez, and Aida Santos. 2002. A Comparative Study of Women Trafficked in the Migration Process: Patterns, Profiles and Health Consequences of Sexual Exploitation in Five Countries (Indonesia, the Philippines, Thailand, Venezuela and the United States). New York: Coalition Against Trafficking in Women.

Seelke, Clare R. 2010. Trafficking in Persons in Latin America and the Caribbean. Washington, DC: Congressional Research Service.

Shelley, Louise. 2010. Human Trafficking: A Global Perspective. New York: Cambridge University Press.

Sigmon, Jane N. 2008. "Combating Modern-Day Slavery: Issues in Identifying and Assisting Victims of Human Trafficking Worldwide." Victims and Offenders 3(2-3):245-57.

United Nations Global Initiative to Fight Human Trafficking (UN.GIFT). 2008. An Introduction to Human Trafficking: Vulnerability, Impact and Action. New York: United Nations.

United States Department of State. 2009. Trafficking in Persons (TIP) Report: June 2009. Washington, DC: Department of State.

Van der Wilt, Harmen. 2014. "Trafficking in Human Beings, Enslavement, Crimes Against Humanity: Unravelling the Concepts." Chinese Journal of International Law 13(2):297-334.

Willis, Jerry W. and Muktha Jost. 2007. Foundations of Qualitative Research: Interpretive and Critical Approaches. Thousand Oaks, CA: Sage.

Yin, Robert K. 2015. Qualitative Research from Start to Finish. New York: Guilford Publications.

\section{TRANSLATED ABSTRACTS}

\section{Sinopsis}

La investigación sobre el tráfico sexual carece considerablemente a pesar de su creciente relevancia mundial. El tráfico de seres humanos ha sido documentado dentro de la literatura como una forma de esclavitud moderna. Se describe comúnemente como una forma de delincuencia organizada que es altamente rentable; involucrando la participación activa de funcionarios corruptos, políticos, instituciones financieras y redes criminales que facilitan la falsificación de documentos, los cruces fronterizos ilegales, el lavado de dinero y el regreso de las víctimas fugitivas. Este documento analiza el análisis de redes temáticas de datos cualitativos recopilados recientemente sobre el tráfico sexual en Belice. El análisis de redes temáticas de Attride-Stirling (2001) se aplicó a los datos recolectados de entrevistas semiestructuradas presenciales con cuatro grupos distintos dentro de la industria del sexo: traficantes sexuales, trabajadoras sexuales, clientes y funcionarios locales bien enterados de la situación Dada la expansiva naturaleza de esta investigación, se ha utilizado el análisis de redes temáticas para acomodar las especificidades de cada grupo, creando lo que se ha denominado aquí como un tema supramundial. Este enfoque innovador facilita el surgimiento de una comprensión más profunda y pertinente de las realidades intrínsecas características de la industria del sexo de Belice y puede aplicarse a investigaciones similares de varios grupos.

Palabras clave: tráfico humano; análisis de redes temáticas; Attride Sterling; corrupción

\section{Résumé}

La recherche sur le trafic sexuel est considérablement insuffisante malgré sa croissante pertinence mondiale. La traite des êtres humains a été documentée dans la littérature comme 
une forme d'esclavage moderne. Il est communément décrit comme une forme de crime organisé hautement rentable; impliquant la participation active de fonctionnaires corrompus, d'hommes politiques, d'institutions financières et de réseaux criminels qui facilitent la falsification de documents, les passages illégaux de frontières, le blanchiment d'argent et le retour des victimes évadées. Ce document discute de l'analyse par réseau thématique de données qualitatives collectées récemment sur le trafic sexuel au Belize. L'analyse du réseau thématique d'Attride-Stirling (2001) a été appliquée aux données recueillies lors d'entretiens face-à-face et semi-structurés avec quatre groupes distincts de l'industrie du sexe: trafiquants d'hommes/femmes, travailleurs du sexe, clients et fonctionnaires locaux. Compte tenu de la nature expansive de cette recherche, l'analyse du réseau thématique a été avancée pour tenir compte des spécificités de chaque groupe, créant ce qui a été appelé ici un thème supraglobal. Cette approche novatrice facilite l'émergence d'une compréhension plus profonde et plus pertinente des réalités intrinsèques caractéristiques de l'industrie du sexe au Belize et peut être appliquée à la recherche similaire des multi-groupes.

Mots-clés: traite des êtres humains; analyse des réseaux thématiques; Attride-Sterling; corruption

\section{摘要}

尽管全球相关性的日益提高, 关于性行为研究仍然相当匮乏。文化中已经将人口 贩运记录为现代奴隶制的一种形式。它通常被描述为一种可谋求暴利的有组织犯 罪形式;涉及腐败官员, 政治家, 金融机构和互联网犯罪的积极参与, 促成文件伪 造, 非法过境点, 洗钱和逃离受害者的返回。本文讨论了最近收集的伯利兹性贩 卖定性数据的专题网络分析。

Attride Stirling (2001) 主题网络分析尝试从性交易相关的行业内与四个不同群体 的面对面, 半结构化访谈收集的数据：性贩子，性工作者, 客户和知识渊博的本 地官员。同时, 为拓宽本研究的特质, 积极推进专题网络分析, 以适应每个群体 的特点, 创造了这里被称为超全球主题。这种创新尝试有助于对伯利兹性行业特 征的内在现实进行更深入, 更有针对性的了解, 并可能应用于类似的多组研究。

\section{关键词：人口贩运，专题网络分析，腐败}

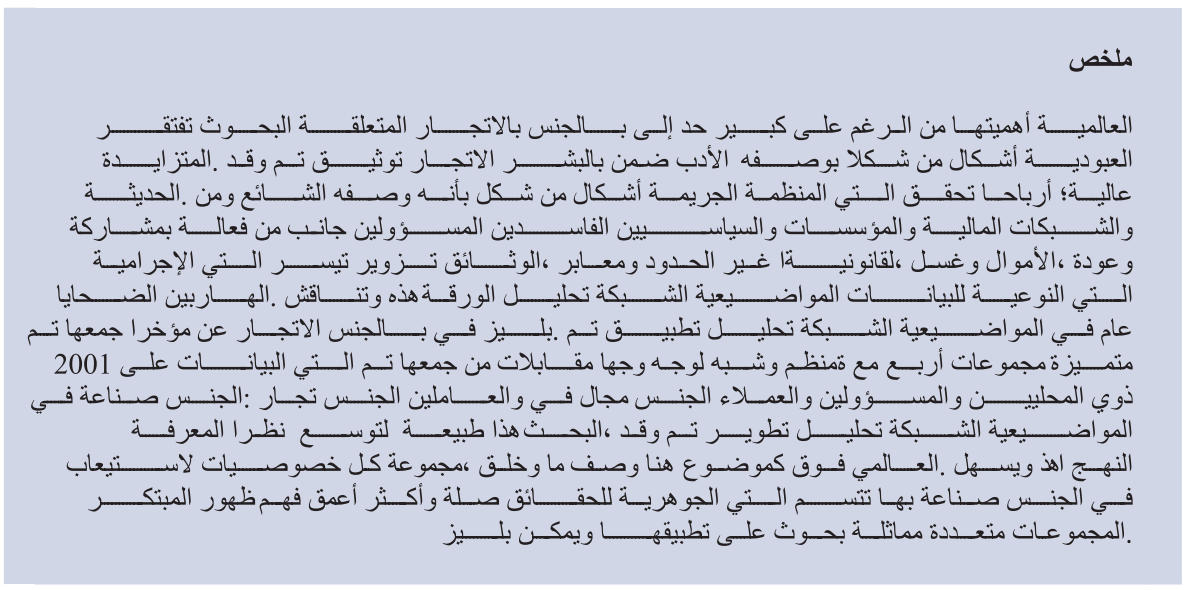

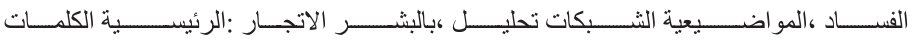


Avekadavie Parasramsingh Mano is a $\mathrm{PhD}$ candidate at the University of the West Indies. Her current research focuses on sex trafficking and sex work in Belize. Through adopting an emic, qualitative approach she has successfully managed to analyze the realities described by multiple groups involved directly and indirectly in the sex industry. In addition, she has explored specific aspects of her research including the vulnerabilities and stigmatization faced by sex workers, the influence of culture and migration on the sex trade as well as the methodological innovation of Attride-Stirling's (2001) thematic network analysis. Her other research interests include assessing the effectiveness of prison policies and programs, the relationships between substance abuse and deviance, the history of crime and theories of criminal behavior.

Cite this article: Mano, A. P. 2017. An Innovative Approach to Sex Trafficking Research: The Methodological Advancement of Attride-Stirling's Thematic Network Analysis. International Annals of Criminology 55: 40-59, doi:10.1017/cri.2017.4 